\title{
The Application of Interest Teaching Mode in College Computer Teaching
}

\author{
Xu Weihua
}

Linyi University, Linyi, Shandong, 276400

Keywords: Interest teaching; Colleges and universities; Computer teaching

\begin{abstract}
In the present era, computer technology is developing rapidly, and its status in people's minds is also higher and higher. In daily work and life, computer technology is widely used. Computer education in Colleges and universities can be a good foundation for advanced computer learning, so people also pay more and more attention to it, which requires school computer classroom efficiency be guaranteed. This paper is to study the scientific application of interest teaching mode in computer teaching in colleges and universities in order to realize teaching purpose.
\end{abstract}

Interest is the best teacher and the power source of student knowledge study. In teaching, appply college students' curiosity so as to improve students' learning interest and enthusiasm for learning and further improve the quality of classroom teaching. Only pay more attention to talent training could the country get development and progress, and personnel training is a process which should begin from an early age. College students, as national hope, should receive higher quality teaching, and computer education in colleges and universities must pay attention to the effectiveness of teaching and cultivate students' logical thinking ability and operation ability. The use of interest teaching mode can increase students' interest in computer learning so that the effectiveness of teaching can be guaranteed. This paper is to study the scientific application of interest teaching mode in computer teaching in colleges and universities in order to realize teaching purpose.

\section{BENEFITS OF INTEREST TEACHING MODE APPLICATION IN UNIVERSITY COMPUTER TEACHING}

Students usually feel computer classroom boring. The application of interest teaching method in computer teaching can let students independently operate computer, feel the charm of computer science so as to improve their learning interest, and eventually make students memorize knowledge more firmly. Interest teaching method, compared to traditional computer teaching model, can arouse the students' interest in learning. Students autonomously operate computer, make the most basic operation ability be improved, and also improve teaching quality.

It is good for students to master computer operation so as to stimulate learning interest

In the course of computer learning, teachers can use interest teaching to increase the curiosity and interest of students so as to explore computer independently. In the classroom, teachers can display wonders of computer operation to the students to attract students' attention in order to make students have the desire to ascertain on computer learning. Once the students have the interest and learning desire of computer learning, they will be conscious to the exploration. In this autonomous exploration process, students can not only master computer knowledge but improve computer operation ability.

\section{Harmonious classroom atmosphere}

Interest teaching mode application in computer teaching not only increase teacher-student interaction session, but also is conducive to the cultivation of the feelings between teachers and students. In usually cases, if students like teachers, they will listen carefully and answer questions actively. If they don't like the teachers, they would not attend the classes and sometimes sabotage. The use of interest teaching method can make students interested in learning computer, and students will also like the computer teacher, thus enhance the emotion between teachers and students, make more active classroom atmosphere and a good teaching environment, which is the premise of improving teaching quality. 


\section{Stimulate students' potential}

In students' daily learning, we can see that students who have particular interest in one subject will pay more effort. On the contrary, if students are not interested in a subject, they would pay relative little effort. Interest teaching methods are more conducive to the cultivation of students learning ability, and promote students' learning. In interest teaching method, students independently explore computer, which not only develop their own potential, but also exercise the thinking ability of the students.

\section{THE SCIENTIFIC APPLICATION OF INTEREST TEACHING MODE IN COLLEGE COMPUTER TEACHING}

\section{The use of students curious psychology to promote interest teaching}

With the rapid development of society, computer has gained popularity, so now before entering high school; most students have contact of computer and know the usages. Under normal circumstances, most of the students are very interested in computer learning, which indicates that students still have internal driving force. Therefore, computer teachers in colleges and universities in interest teaching can make full use of student's curiosity to computer. For example, in computer teaching of making slides, teachers can show students self-made slide in advance in teaching, and select topics of students interest as the content of the slide, which can be a figure of fun, also be hits nowadays. Arouse student's interest through the slide show to mobilize students' learning enthusiasm of making slides. Using students' curiosity psychology to promote interest teaching and mobilize the students' enthusiasm for learning can help to create a harmonious computer classroom atmosphere for learning. The harmonious classroom atmosphere is the prerequisite for the students to study effectively, and they blend and promote each other, thus achieve the goal of teaching.

\section{Using computer games to promote interest teaching}

College students are generally fond of playing games. Games have a certain interest and challenge, which can exercise thinking ability and make people's emotional awareness enhanced. Using computer games can improve the interest of students' computer learning which is very effective. Usually students are uninterested in computer knowledge explanation, but if intersperse a number of small games in computer classroom, and each student can participate, then explain knowledge and teach some computer basic operation methods, which will effectively enhance students' interest. For example, some students are not good in language and math learning achievements, but are proficient in computer related knowledge, because they like operation. The teacher can encourage students to study, which will be active in class and learning achievement is improved. It can improve students teaching quality by using computer games appropriately.

\section{Promote interest teaching by using activity contest way}

After students' repeated operation of computer for a long time, sooner or later they will feel dull and tired. Therefore, teachers should consider the characteristics of students' personality. Holding some games and activities about computer knowledge in order to fully mobilize the enthusiasm of students computer learning and make classroom atmosphere more active so that the students not only grasp the knowledge, but the practical operation and thinking ability have been effectively improved. For example, before word knowledge teaching, teachers can make prior notice that after the content learning, there will be word operation game. Students can freely get into groups, and the excellent work team members will be awarded a certificate of merit so as to arouse students' interest in learning in the classroom and classroom learning atmosphere has become more intense, which will not only improve the interest of students in computer learning, but cultivate team cooperation ability.

\section{THE PRINCIPLES OF INTEREST TEACHING APPLICATION IN COMPUTER TEACHING IN COLLEGES AND UNIVERSITIES}

\section{Stimulate interest}

Interest is the best teacher in learning. In student computer teaching, apply interest teaching is mainly to fully mobilize students' enthusiasm. In harmonious teaching environment, let the student 
actively learn computer. Interest teaching needs to begin from students and stimulate students' interest in learning, which has an important role in the growth and learning of the students. Computer course is an indispensable for knowledge learning. To master computer knowledge can be the base for other discipline knowledge learning. Computer teaching is the cultivation of students' comprehensive ability, imagination and innovation ability. The application of interest teaching method is to improve students' computer learning interest. First of all, in accordance with students interests, construct a harmonious learning environment. In this environment, teachers and students can make equal interaction and communication, and students can also be ease, enthusiastic, and actively play their imagination. Have the best state in computer learning. Stimulate interest plays an important role in the teaching of computer in colleges and universities, which plays an important role in the communication between teacher and students, stimulate students' interest, let students be footloose and fancy free in expression of their feelings, thoughts, etc. and appear these through the text. It is not only to achieve the happy teaching of college students, but also increase the computer level of students. College students in computer teaching can give full play to their creativity and imagination by stimulating interests.Improve teaching method and enhance the interest of study

Interest is the basis for students' learning and progress. Teachers should update teaching methods, understand students learning characteristics and ideological status, and develop a more suitable teaching program for students. For example, in daily study, the organization of a number of games on computer skills can encourage students' participation enthusiasm. Take competition as a driving force, and stimulate their initiative and self-esteem. Let the students in preparation and competition process develop their thinking and take the initiative to seek ways to solve more problems. Determine the main status of students so that teaching work is focused on strengthening the students' thinking skills, and put emphasis on imparting work of problem solving methods [3]. With the rapid development of computer technology, let students strengthen their ability to deal with problems independently, and keep the teaching methods of theory and practice. For example, in word chapter, the teachers first briefly introduce textbook illustrations. Then, guide students operate software operation. Through the introduction of menu bar options one by one, students feel word formation process. Finally, encourage students to play freely, and complete a text creation work independently, so as to achieve the students' ability to study independently.

\section{Make reasonable teaching tasks and teach students in accordance with their aptitude}

Computer teaching material is highly specialized, and the knowledge boundary is vague. The teacher should understand and conclude the substance of the outline, and make the appropriate change of the materials and the actual. Different students have different learning interest. Some like programming knowledge, some like writing, and some like hardware, teachers should give correct knowledge guide according to the students' likes so that it can be brought into full play. In addition, give guidance respectively to students learning personality. The teacher should strengthen the communication with the students, make the teacher's caring teaching more interactive and create a good teaching atmosphere. For the students with low learning level, give patient explanation and guidance and strengthen their confidence.

\section{Reasonably use teaching software to provide students with good learning environment}

In fact, many methods can help students improve computer learning ability, for example, open the computer room and install some valuable teaching software on the computer, so students can have a choice of learning and mastering of knowledge points according to their own characteristics. This is not only conducive to the use rate of computer equipment, but also will provide more perfect learning environment for students. At this stage, suitable teaching software includes "Five pen" and "Master Flash learning software". If the school conditions permit, share computer testing software and courseware on the Internet, and evaluate students' computer learning effect through the test software.

Take students as the main body of teaching to enhance students self-learning ability

Apply "Teacher leading, student-centered" teaching model in computer teaching to cultivate students' creative thinking and enhance the ability of self-study which is extremely beneficial. As 
already mentioned, computer is a strong operational and practical discipline, and some knowledge needs students' practice to master, so if students' main role is into full play to learn computer, and have comprehensive training of students' creative thinking and self-learning ability, computer classroom should abandon the previous cramming teaching, and should be combined with the characteristics of computer science. Make fewer lectures, pay attention to the classroom teaching efficiency and teaching quality, and encourage students to actively learn computer knowledge through effective teaching method.

\section{CONCLUSION}

At present, computer technology has been developing rapidly, and its status is also higher and higher in people's minds. It has been widely used in daily life. Computer course in colleges can lay a good foundation for advanced computer learning, so people pay more and more attention to computer education in colleges and universities. School computer classroom efficiency requirements must be guaranteed. Application of interest teaching mode in college computer teaching effectively stimulates students' interest of learning computer, fully mobilizes learning initiative, and creates a good atmosphere in the classroom, so as to inspire students' thinking and improve teaching quality. Teachers in computer teaching, should improve their own information technology, pay attention to innovation, and choose a variety of channels in the application of interest teaching mode. Only in this way can we finally achieve teaching objectives.

\section{REFERENCES}

[1] Li Shengxin, Xie Guifang, Zhong Liang, et al. The application of interest teaching mode in university computer public class [J]. Fujian Computer, 27, 2011 (9): 35-36.

[2] Wang Jing, Li Hongyang, Jiang Yanjing. On the application of interest driven method in computer network course teaching [J]. Modern Business Industry, 2009, 21 (23): 226-227.

[3] Ren Fangning. Task driven teaching method application and research in Military Medical University "Computer Application Foundation" teaching [D]. The Fourth Military Medical University, 2012:11-12.

[4] Wang Xianping. The application of "Interest Teaching Method" in computer teaching [J]. Modern Communication Monthly, 2012, (12): 209-209.

[5] Wu Nan. Analysis of the application of problem teaching mode in university computer basic teaching [J]. Journal of Jiamusi Institute of Education, 2009, (9): 90-91.

[6] Liu Jun. Application of task driven method in university computer course teaching [J]. Journal of Chifeng University: Science Education Edition, 2011, (11): 256-257.

[7] Lin Xiaoran. Application of “Teaching in Contests, Contests for Teaching” method in computer experiment teaching [J]. Modern Computer, 2013, (13): 38-39. 